\title{
Yüksek Serum Osmolalitesi Akut Ülseratif Kolit Hastalarında Hastalık Şiddetini Tahmin Edebilir
}

\section{High Serum Osmolality May Predict the Disease Severity in Patients with Acute Ulcerative Colitis}

\author{
${ }^{1}$ Abdussamed VURAL, ${ }^{2}$ Asl VURAL, ${ }^{3}$ Selahattin VURAL, ${ }^{1}$ Selim TURFAN, ${ }^{4}$ Ahmet Cumhur DÜLGER \\ ${ }^{1}$ Giresun University Prof. Dr. İlhan Özdemir Training and Research Hospital, Emergency Medicine, Giresun, Turkey \\ ${ }^{2}$ Giresun University Prof. Dr. İlhan Özdemir Training and Research Hospital, Cardiology, Giresun, Turkey \\ ${ }^{3}$ Giresun University Prof. Dr. İlhan Özdemir Training and Research Hospital, General Surgery, Giresun, Turkey \\ ${ }^{4}$ Giresun University Prof. Dr. İlhan Özdemir Training and Research Hospital, Gastroenterology and Hepatology, Giresun, Turkey
}

\author{
Abdussamed Vural: https://orcid.org/0000-0003-4506-916X \\ Asl1 Vural: https://orcid.org/0000-0002-6592-3100 \\ Selahattin Vural: https://orcid.org/0000-0003-1706-3799 \\ Selim Turfan: https://orcid.org/0000-0003-3524-2512 \\ Ahmet Cumhur Dülger: https://orcid.org/0000-0002-9328-5185
}

\section{ÖZ}

Amaç: Ülseratif kolit (ÜK), kolon mukozasının kronik immün aracilı enflamasyonu ile karakterizedir. ÜK'nin ciddiyetini tanımlamak için Truelove ve Witts (TW) kriterleri kullanılmıştır. Diğer taraftan, ÜK'li yüksek riskli hastaların daha iyi tanımlanabilmesi için daha basit bir laboratuvar aracına ihtiyaç vardır. Çalışmanın amacı, özellikle acil servis uygulamalarında, hastanın semptomatik tedaviden sonra hastaneye yatırılması gerekliliğini öngörebilen ve hastalığın ciddiyetini kolayca ve hızlı bir şekilde tahmin edebilen bir biyobelirteç olarak serum osmalalitesinin yararlılığını belirlemektir.

Materyal ve Metot: $\mathrm{Bu}$ tek merkezli, retrospektif kohort çalışmasında ÜK'li 62 hastanın demografik özellikleri ve kan örnek sonuçları değerlendirildi ve veriler toplandı. Serum osmolalitesi ile birlikte hastaların Truelove ve Witts (TW) skorları hesaplandi. Data analizinde stata 14.0. paket programı kullanıldı. $\mathrm{P}<0,05$ istatiksel olarak anlamlı kabul edildi.

Bulgular: Çalıșma sonunda, yüksek osmolaliteli hastaların daha yüksek olasılıkla şiddetli ülseratif kolite, yüksek TW skoru, sahip oldukları görülmüștür.

Sonuç: Sonuç olarak, serum osmolalitesi hastalığın ciddiyetini göstermek için yararlı bir belirleyici olarak düşünülebilir.

Anahtar Kelimeler: Akut ülseratif kolit, serum ozmolalitesi, Truelove Witt's skoru

\section{ABSTRACT}

Objective: Ulcerative colitis (UC) is characterised by chronic immun- mediated inflammation of the colonic mucosa. The Truelove and Witts (TW) criteria have been used to define the severity of the UC. Otherhand, a simplier and unified laboratory tool is needed for better definition of high risk patients with UC. The aim of the study, especially in emergency service applications, was to determine the usefulness of serum osmalality as a biomarker which can easily and rapidly predict the severity of the disease, in which the patient will be advised to be hospitalized after the symptomatic treatment.

Materials and Methods: In this single-center, retrospective cohort study, we collected data of 62 hospitalized patients with UC such as demographic characteristics and blood sample results evaluated by clinicians. Truelove and Witts (TW) scores of the patients along with serum osmolality were calculated. Stata 14.0. package program was used for data analysis. $\mathrm{P}<0.05$ was considered statistically significant.

Results: According to our results, patients with hyperosmolality were more likely to have severe UC as defined by having higher scores of TW criteria at baseline.

Conclusion: As a conclusion, serum osmolality can be considered as an useful predictor to demonstrate the severity of the disease

Keywords: Acute ulcerative colitis, serum osmolality, Truelove Witt's score

Yayın Bilgisi / Article Info:

Gönderi Tarihi/ Received: 09/01/2019

Abdussamed Vura

Giresun University Training and Research Hospital, Giresun, TURKEY

Online Yayın Tarihi/ Published: 30/06/2020

Emergency Medicine Departmant, Giresun, TURKEY

Postal zip code: 28200

Phone: +905064811070

Fax: (454) 2155146

E-mail: abdussamedvural@gmail.com

Atıf/Cited: Vural A, et al. High Serum Osmolality May Predict the Disease Severity in Patients with Acute Ulcerative Colitis. Online Türk Sağllk Bilimleri Dergisi 2020;5(2):324-329. doi: 10.26453/otjhs.510969 


\section{INTRODUCTION}

Ulcerative colitis (UC) is characterised by chronic immun- mediated inflammation of the colonic mucosa. One-fifth of patients with UC will experience an acute flare requiring hospitalization. This is a medical emergency and requires prompt recognition and multidisciplinary management. ${ }^{1}$ Active disease in severe UC also causes a major health burden with increasing global incidence of the disease.

Colonoscopy is the standart procedure for diagnosing ulcerative colitis and histopathological examination of the biopsy specimens of the colonic mucosa usually shows lympocytic cryptit and distortion of the villi. ${ }^{2}$

The Truelove and Witts (TW) criteria have been used to define the severity of the UC since $1954 .{ }^{3}$ and this criteria are most widely used to define active severe colitis. ${ }^{4,5} \mathrm{TW}$ score measures disease activity based on the mucosal ulcers and fragility in connection with some laboratory parameters and is a robust tool for clinical approach to the patient. Calculation of TW scores may help in stratifying the risk of disease activity and detailed screening and surveillance. The TW-based severe UC is defined as more than six blood stained stools daily, with 1 or more of the 4 additional criteria: hemoglobin level below than $10.5 \mathrm{~g} / \mathrm{dl}$, erithrocyte sedimentation rate higher than $30 \mathrm{~mm} /$ hour, fever higher than $37.8^{\circ} \mathrm{C}$, and sinus tachycardia greater than $90 / \mathrm{min}^{6}{ }^{6}$

Serum osmolality is a key element of neurohormonal activation and may influence to certain medical agents in patients with severe illnesses such as hearth failure. ${ }^{7}$ In normal subjects, the serum osmolality is calculated from the following formula: Plasma osmolality $(\mathrm{mOsm} / \mathrm{kg})=2 \mathrm{x}\left(\mathrm{Na}^{+}+\mathrm{K}^{+}\right)+$glucose $/ 18+$ urea/6 (glucose and urea are expressed as $\mathrm{mg} / \mathrm{dL}$, while $\mathrm{K}^{+}$and $\mathrm{Na}^{+}$in $\mathrm{mmol} / \mathrm{L}$ ). If urea nitrogen (BUN) is measured, then the BUN/2.8 should be utilized in the equation instead of urea/ 6 is also acceptable. ${ }^{8}$ In normal conditions, serum osmolality are ranged from 275 to $295 \mathrm{mOsm} / \mathrm{kg}$.

Otherhand, a simplier and unified laboratory tool is needed for better definition of high risk patients with UC. However, there is no consensus for the value of serum osmolality during pre-colonoscopy period for those patients with severe UC.

\section{MATERIALS AND METHODS}

In this single-center, retrospective cohort study, we collected data from 62 patients with ulcerative colitis who were hospitalized to hospital between 1 January 2017 and 1 July 2018 and evaluated by gastroen- terologists. These data were collected retrospectively from a national university training and research hospital data system and official approval was obtained for the use of this data (29.05.2020 / 85554271-929). Patients who were pregnant or younger than 17 years old or were taking steroids, mannitol, radiocontrast agents, alcohol, ethylene glycol were excluded from this analysis. In addition, patients with surrenal and thyroid diseases were also excluded from the study. The following information was extracted: age, gender, hematologic and biochemical markers, serum levels of TSH, cortisol, $\mathrm{Na}^{+}, \mathrm{K}^{+}$, glucose, urea, creatinine and albumin. We diagnosed acute severe colitis using the conventional Truelove and Witts criteria and serum osmolarity was calculated using the equation $\left(2 \times \mathrm{Na}^{+}+\mathrm{K}^{+}\right)+($glucose/18) + (BUN/2.8). ${ }^{8,10}$

Statistical Analysis: If a $\mathrm{P}$ value was lower than 0.05 , it was considered as statistically significant. All confidence intervals (CI) quoted are 95\% CI. Multivariate logistic analysis was performed to calculate odds ratios, adjusting for sociodemographics, patient characteristics, comorbidities and code status. Analysis was performed using Stata 14.0.

\section{RESULTS}

The age (mean $\pm \mathrm{SD}$ ) of participants was $54.5 \pm 6.5$ years and $30(48 \%)$ were women. At baseline, UC duration (mean $\pm \mathrm{SD}$ ) was $4.2 \pm 2.8$ years. Two-thirds had extensive colitis and one-third had higher TW scores. The baseline characteristics of patients in the study were shown in Table 1.

According to our study results; Patients with hyperosmolality were more likely to have severe UC as defined by having higher scores of TW criteria at baseline .

Cross sectionally, higher serum osmolality was correlated with higher baseline creatinine $(\mathrm{r}=-0.1$, $\mathrm{CI}=0.7$ to $0.8 ; \mathrm{p}<0.001$ ), higher $\mathrm{CRP}(\mathrm{r}=0.8 ; \mathrm{CI}: 0.3$ to $1.2 ; \mathrm{p}=0.01$ ), higher $\mathrm{WBC}$ ( $\mathrm{r}=3.2$; CI:6.6 to 8.5 ; $\mathrm{P}=0.016)$, greater $\mathrm{MCV} \quad(\mathrm{r}=8.9 ; \mathrm{CI}=82$ to 87 ; $\mathrm{p}=0.018)$; lower hematocrit $(\mathrm{r}=5 ; \mathrm{CI}=37$ to $41 ; \mathrm{p}=$ $0.043)$ and lower albumin ( $\mathrm{r}=0.5, \mathrm{CI}=4.5$ to 4.8 ; $\mathrm{p}<0.001)$ levels. A summary of the data can be found on Table 2.

\section{DISCUSSION AND CONCLUSION}

Serum osmolality plays a key role in extracellular and intracellular osmotic status and determined by the concentrations of $\mathrm{Na}^{+}, \mathrm{K}+, \mathrm{Cl}_{-}$, glucose and urea. Hyperosmolality mostly caused by detoriation of main contributing elements of the serum osmo- 
lality including serum sodium and serum glucose in critically ill patients. ${ }^{11,12}$

It has been also demonstrated that dehydration and hypernatraemia could cause elevated serum osmolality in patients with gastrointestinal disorders with thresholds at $300 \mathrm{mmoL} / \mathrm{L}$. Hyperosmolarity was also linked to increased hospital and ICU mortality compared with normal osmolarity levels. ${ }^{13}$ The normal range of serum osmolality is defined as 275 $295 \mathrm{mOsm} / \mathrm{kg}$ of water. ${ }^{9}$ It has been showed that increased resting sympathetic activity and blood pressure could be related to acutely elevated plasma osmolality. ${ }^{14}$

In a recent publication authors reported that UC also triggers a complex cascade of metabolic responses that can cause fluid-electrolyte disturbances such as hypernatremia. Authors also showed that colonic dysfunction is an important contributor to serum osmolality, due to the critical roles of colonic mucosa for regularity of sodium and electrolyte balance. $^{15,16}$

In vitro studies of the net transport and concomitant two-way influx rates of water and electrolytes along the human colonic epithelium showed that in case of UC the colon had diminished capacity absorption and had increased capability of secretion. Specifically, in the acute severe UC; colon absorbs less water and salt and secretes more potassium. ${ }^{17}$

There were several limitations of the study. First, patient bias may have been existed due to retrospective nature of the study. Second, study findings may not be generalized entire the population due to small sample size. Lastly, we did not obtain the data involving osmolal gap.

Further studies are needed to determine a causal link between serum osmolality and UC.

As a conclusion; Serum osmalality can be considered as a useful tool in demonstrating the severity of the disease in addition to clinical, hemodynamic and other laboratory tests of patients as a guide in the management of patients admitted to the hospital with ulcerative colitis attack. The serum osmalality as a laboratory marker can be useful and should be part of the global management of UC patients. But further studies are needed to determine a causal link between serum osmolality and UC because of several limitations of the study.

Ethics Committee Approval: In this single-center, retrospective cohort study, the data were collected retrospectively from a national university training and research hospital data system and official approval was obtained for the use of this data. ( 29.05.2020/ 85554271-929)

Conflict of Interest: No conflict of interest was declared by the authors.

Author Contributions: Concept-ACD; Supervision- SV; Materials - AV, ST; Data Collection and/or Processing $\mathrm{AV}, \mathrm{ST}$; Analysis and/ or Interpretation-ACD, AV; Writing -AV, ACD.

Peer-review: Externally peer-reviewed.

Acknowledgement: The authors thank to the peer reviewers for their comments, which have helped to improve the paper.

\section{REFERENCES}

1. Dulai PS, Jairath V. Acute severe ulcerative colitis: latest evidence and therapeutic implications. Ther Adv Chronic Dis. 2018;9(2):65-72.

2. Danese S, Banerjee R, Cummings JF et al. Consensus recommendations for patient-centered therapy in mild-to-moderate ulcerative colitis: the i Support Therapy-Access to Rapid Treatment (iSTART) approach. Intest Res. 2018;16 (4):522-528.

3. Truelove SC, Witts LJ. Cortisone in ulcerative colitis; preliminary report on a therapeutic trial. Br Med J. 1954;2:375-378.

4. Mowat C, Cole A, Windsor A, et al. Guidelines for the management of inflammatory bowel disease in adults. Gut. 2011;60:571-607.

5. Brown SR, Haboubi N, Hampton J, George B, Travis SP. ACPGBI. The management of acute severe colitis: ACPGBI position statement. Colorectal Dis. 2008;10(Suppl 3):8-29.

6. Jain S, Kedia S, Bopanna S. et al. Are Truelove and Witts criteria for diagnosing acute severe colitis relevant for the Indian population? A prospective study. Intest Res. 2018;16(1):69-74.

7. Vaduganathan M, Marti CN, Mentz RJ, Serum Osmolality and Postdischarge Outcomes After Hospitalization for Heart Failure. Am J Cardiol. 2016;117(7):1144-1150.

8. Liamis G, Filippatos TD, Liontos A, Elisaf M1. Serum osmolal gap in clinical practice: usefulness and limitations. Postgrad Med. 2017;129 (4):456-459.

9. Rasouli M. Basic concepts and practical equations on osmolality: Biochemical approach. Clin Biochem. 2016;49(12):936-941.

10. Heavens KR, Kenefick RW, Caruso EM, et al. Validation of equations used to predict plasma osmolality in a healthy adult cohort. Am J Clin Nutr. 2014;100:1252-1256.

11. Wannamethee SG, Shaper AG, Lennon L, et al. 
Mild hyponatremia, hypernatremia and incident cardiovascular disease and mortality in older men: a population-based cohort study. Nutrition, Metabolism and Cardiovascular Diseases. 2016;26:12-19.

12. Xie J, Cui K, Hao H, et al. Acute hyperglycemia suppresses left ventricular diastolic function and inhibits autophagic flux in mice under prohypertrophic stimulation. Cardiovasc Diabetol. 2016;15:136

13. Shen Y, Cheng X, Ying $M$ et al. Association between serum osmolarity and mortality in patients who are critically ill: a retrospective cohort study. BMJ Open. 2017;7(5):e015729.

14. Brian MS, Matthews EL, Watso JC, et al. The influence of acute elevations in plasma osmolality and serum sodium on sympathetic outflow and blood pressure responses to exercise. J Neurophysiol. 2018;119(4):1257-1265.

15. Zhang M, Sun K, Wu Y, Yang Y, Tso P2, Wu Z. Interactions between Intestinal Microbiota and Host Immune Response in Inflammatory Bowel Disease. Front Immunol. 2017;8:942.

16. Hindryckx P, Jairath V, D'Haens G. Acute severe ulcerative colitis: from pathophysiology to clinical management. Nat Rev Gastroenterol Hepatol. 2016;13(11):654-664.

17. Archampong EQ, Harris J, Clark CG. The absorption and secretion of water and electrolytes across the healthy and the diseased human colonic mucosa measured in vitro. Gut. 1972;13 (11):880-886. 
Table 1. Baseline characteristics of the patients in the study (n: 62).

\begin{tabular}{|l|c|c|c|}
\hline \multirow{2}{*}{ Age } & Minimum & Maximum & Mean \pm SD \\
\cline { 2 - 4 } & Statistic & Statistic & Statistic \\
\hline Hemoglobin (gr/dl) & 19.00 & 78.00 & $54.1250 \pm 17.31445$ \\
\hline Anion gap (mEq/L) & 10.20 & 17.50 & $12.7031 \pm 1.77482$ \\
\hline Osmolality (mOsm/kg) & 12.70 & 19.30 & $15.5222 \pm 1.99987$ \\
\hline Chlorine (mmol/L) & 288.50 & 309.00 & $295.7438 \pm 5.42693$ \\
\hline Hematocrit (\%) & 32.60 & 107.00 & $101.9688 \pm 2685$ \\
\hline Tsh (mIU/L) & 0.22 & 52.70 & $39.4813 \pm 4.64518$ \\
\hline Sodium (mmol/L) & 138.00 & 148.00 & $1.8965 \pm 1.33913$ \\
\hline Ferritine (ng/mL) & 4.18 & 229.20 & $54.7973 \pm 59.45761$ \\
\hline Crp (mg/dL) & 0.03 & 4.93 & $0.8106 \pm 1.16337$ \\
\hline Potassium (mmol/L) & 3.83 & 5.41 & $4.7003 \pm 0.34951$ \\
\hline MCV (fL/red cell) & 68.80 & 96.90 & $85.0563 \pm 6.14124$ \\
\hline ALT (IU/L) & 4.00 & 66.00 & $22.4375 \pm 17.16887$ \\
\hline Albumine (mg/dl) & 3.50 & 5.30 & $4.6967 \pm 0.45749$ \\
\hline Creatinine (mg/dl) & 0.52 & 1.25 & $0.8003 \pm 0.20421$ \\
\hline Wbc (x 10 $/ \mathbf{L})$ & 2.64 & 15.39 & $7.5981 \pm 2.50219$ \\
\hline Glucose (mg/dl) & 84.00 & 220.00 & $115.9063 \pm 32.33530$ \\
\hline Plt (x 10 / $/ \mathbf{\mu L )}$ & 128.00 & 438.00 & $279.9688 \pm 85.34578$ \\
\hline Urea (mg/dl) & 11.00 & 49.00 & $30.2813 \pm 10.39303$ \\
\hline AST (IU/L) & 9.00 & 68.00 & $22.6250 \pm 12.32032$ \\
\hline
\end{tabular}


Table 2. Comparison of osmolality with other parameters.

\begin{tabular}{|c|c|c|c|c|c|c|}
\hline \multicolumn{2}{|c|}{ ANOVA TEST } & Sum of Squares & df & Mean Square & $\mathbf{F}$ & Sig \\
\hline \multirow{3}{*}{ Age } & Between Groups & 9037.833 & 25 & 361.513 & 8.484 & 0.007 \\
\hline & Within Groups & 255.667 & 6 & 42.611 & & \\
\hline & Total & 9293.500 & 31 & & & \\
\hline \multirow{3}{*}{$\begin{array}{l}\text { Hemoglobin } \\
\text { (gr/dl) }\end{array}$} & Between Groups & 90.665 & 25 & 3.627 & 3.115 & 0.080 \\
\hline & Within Groups & 6.985 & 6 & 1.164 & & \\
\hline & Total & 97.650 & 31 & & & \\
\hline \multirow{3}{*}{$\begin{array}{l}\text { Chlorine } \\
(\mathrm{mmol} / \mathrm{L})\end{array}$} & Between Groups & 141.302 & 25 & 5.652 & 1.433 & 0.346 \\
\hline & Within Groups & 23.667 & 6 & 3.944 & & \\
\hline & Total & 164.969 & 31 & & & \\
\hline \multirow{3}{*}{$\begin{array}{l}\text { Potassium } \\
(\mathrm{mmol} / \mathrm{L})\end{array}$} & Between Groups & 3.415 & 25 & 0.137 & 2.206 & 0.164 \\
\hline & Within Groups & 0.372 & 6 & 0.062 & & \\
\hline & Total & 3.787 & 31 & & & \\
\hline \multirow{3}{*}{$\begin{array}{l}\text { Creatinine } \\
(\mathrm{mg} / \mathrm{dl})\end{array}$} & Between Groups & 1.273 & 25 & 0.051 & 15.272 & 0.001 \\
\hline & Within Groups & 0.020 & 6 & 0.003 & & \\
\hline & Total & 1.293 & 31 & & & \\
\hline \multirow{3}{*}{$\begin{array}{l}\text { Tsh } \\
(\mathbf{m I U} / \mathbf{L})\end{array}$} & Between Groups & 53.000 & 25 & 2.120 & 4.908 & 0.028 \\
\hline & Within Groups & 2.592 & 6 & 0.432 & & \\
\hline & Total & 55.592 & 31 & & & \\
\hline \multirow{3}{*}{$\begin{array}{l}\text { Sodium } \\
(\mathbf{m m o l} / \mathbf{L})\end{array}$} & Between Groups & 158.333 & 25 & 6.333 & 4.957 & 0.027 \\
\hline & Within Groups & 7.667 & 6 & 1.278 & & \\
\hline & Total & 166.000 & 31 & & & \\
\hline \multirow{3}{*}{$\begin{array}{l}\text { Ferritine } \\
(\mathrm{ng} / \mathrm{mL})\end{array}$} & Between Groups & 97937.838 & 23 & 4258.167 & 5.575 & 0.020 \\
\hline & Within Groups & 4583.163 & 6 & 763.860 & & \\
\hline & Total & 102521.001 & 29 & & & \\
\hline \multirow{3}{*}{$\begin{array}{l}\text { CRP } \\
(\mathrm{mg} / \mathrm{dL})\end{array}$} & Between Groups & 40.092 & 24 & 1.671 & 19.633 & 0.010 \\
\hline & Within Groups & 0.511 & 6 & 0.085 & & \\
\hline & Total & 40.603 & 30 & & & \\
\hline \multirow{3}{*}{$\begin{array}{l}\text { ALT } \\
(\mathbf{I U} / \mathbf{L})\end{array}$} & Between Groups & 8439.375 & 25 & 337.575 & 2.900 & 0.094 \\
\hline & Within Groups & 698.500 & 6 & 116.417 & & \\
\hline & Total & 9137.875 & 31 & & & \\
\hline \multirow{3}{*}{$\begin{array}{l}\text { Albumine } \\
(\mathrm{mg} / \mathrm{dl})\end{array}$} & Between Groups & 5.978 & 23 & 0.260 & 17.012 & 0.001 \\
\hline & Within Groups & 0.092 & 6 & 0.015 & & \\
\hline & Total & 6.070 & 29 & & & \\
\hline \multirow{3}{*}{$\begin{array}{l}\text { AST } \\
(\mathbf{I U} / \mathbf{L})\end{array}$} & Between Groups & 4310.333 & 25 & 172.413 & 2.618 & 0.116 \\
\hline & Within Groups & 395.167 & 6 & 65.861 & & \\
\hline & Total & 4705.500 & 31 & & & \\
\hline \multirow{3}{*}{$\begin{array}{l}\text { Hematocrit } \\
(\%)\end{array}$} & Between Groups & 631.737 & 25 & 25.269 & 4.079 & 0.043 \\
\hline & Within Groups & 37.172 & 6 & 6.195 & & \\
\hline & Total & 668.909 & 31 & & & \\
\hline \multirow{3}{*}{$\begin{array}{l}\text { Urea } \\
(\mathrm{mg} / \mathrm{dl})\end{array}$} & Between Groups & 3135.302 & 25 & 125.412 & 3.530 & 0.061 \\
\hline & Within Groups & 213.167 & 6 & 35.528 & & \\
\hline & Total & 3348.469 & 31 & & & \\
\hline \multirow{3}{*}{$\begin{array}{l}\text { Wbc } \\
\left(\begin{array}{ll}x & \left.10^{9} / L\right)\end{array}\right.\end{array}$} & Between Groups & 186.729 & 25 & 7.469 & 6.089 & 0.016 \\
\hline & Within Groups & 7.360 & 6 & 1.227 & & \\
\hline & Total & 194.089 & 31 & & & \\
\hline \multirow{3}{*}{$\begin{array}{l}\text { MCV } \\
\text { (fL/red cell) }\end{array}$} & Between Groups & 1122.447 & 25 & 44.898 & 5.767 & 0.018 \\
\hline & Within Groups & 46.712 & 6 & 7.785 & & \\
\hline & Total & 1169.159 & 31 & & & \\
\hline \multirow{3}{*}{$\begin{array}{l}\text { Glucose } \\
(\mathrm{mg} / \mathrm{dl})\end{array}$} & Between Groups & 24741.052 & 25 & 989.642 & 0.774 & 0.703 \\
\hline & Within Groups & 7671.667 & 6 & 1278.611 & & \\
\hline & Total & 32412.719 & 31 & & & \\
\hline & Between Groups & 204286.469 & 25 & 8171.459 & 2.279 & 0.154 \\
\hline Plt & Within Groups & 21514.500 & 6 & 3585.750 & & \\
\hline & Total & 225800.969 & 31 & & & \\
\hline
\end{tabular}

Table Description : Osmolality- Evaluated One Way Anova Test Between Other Parameters.

According to this table, higher serum osmolality was correlated with higher baseline creatinine $(p<0.001)$, higher CRP $(p=0.01)$, higher WBC ( $p=0.016)$, greater MCV $(p=0.018)$; lower hematocrit $(p=0.043)$ and lower albumin $(p<0.001)$. All these findings were considered as statistically significant. 